\title{
強力レーヨンの酢化とその微細構造変化について
}

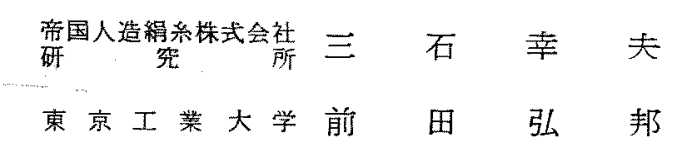

\section{FIBROUS ACETYLATION OF HIGH TENACITY RAYON AND ITS FINE STRUCTURAL CHANGES}

\author{
By Yukio Mitsuishi
}

(Research Laboratory, Teikoku Rayon Co., Ltd., Iwakuni City, Yamaguchi Prefecture, Japan)

\section{By Hirokuni Maeda}

(Laboratory of Textile Chemistry, Tokyo Institute of Technology, Meguro-ku, Tokyo, Japan)

All-skin type high tenacity rayon was acetylated in fibrous form in the mixture of acetic anhydride and xylene using $\mathrm{CH}_{3} \mathrm{COONa}$ as catalyzer. The mechanical properties, namely strength, elongation and especially the elastic recovery behavior of the acetylated samples with various acetyl contents were measured. At $0,1 \sim 0.5$ degree of acetylation the elastic recovery of acetylated samples increases and above that degree, it decreases. The $\mathrm{X}$-ray patterns of partially acetylated rayon samples did not show any remarkable change from that of the original rayon sample until about $0.4 \sim 0.5$ degree of acetylation, namely, in so far as the acetylation reaction followed the lst order reaction.

(Received September 14, 1961)

\section{1. 緒霉}

P. Herrent 和よび A.Lude $3 \supset$ double network 棰造は一般にレーシンの突在の姿 に最与近い模型と考えられているが，最近の強力レーヨ ンはこの製造滑程その他種々の物性より考灾てもさらに この模型に近いるのであることが想像される。すなわら 充导心伸長された各鎖状分子は多数の結晶領域，無定形 領域を貫透して，いかゆる速続ミセル構造をとりながら 全体として primary network を構成し，各結晶領域は

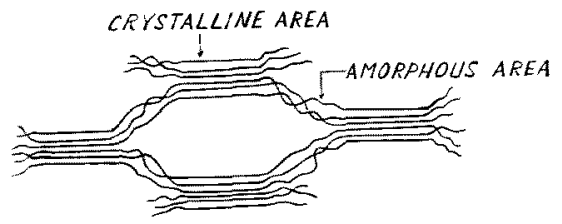

a. PRIMARY NETWORK

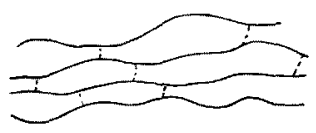

6. SECONDARY NETWORK

Fig 1. Schematic double network structure.
その結び目となつている。さらに結晶領域と結晶領域を 連結する無定形領域心おいては办素結合を含む種々の2 次的分子間力によつてせルトースは灌集しいわわる secondary network 满成している。この secondary net-

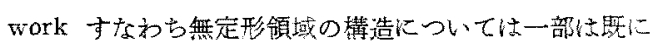
発表しだ。その結果からかかのたことはこの secondary network を構成している分子間の結合には種々の强 さのものがありレーミンの整造方法なと゚相違によつて 種々異なる分有をもつている。
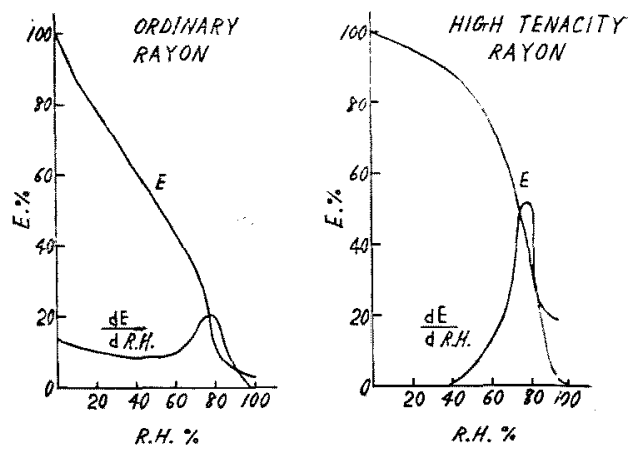

Fig 2. Summative mass-order and its distribution curve for cohesive energy in amorphous area. 
例觉ば普通レーヨンとオールスキン型の珫力レーヨン

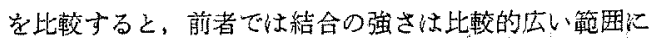
分布する加，後者で相䇃湿度 $80 \%$ 内外の水蒸氛で破

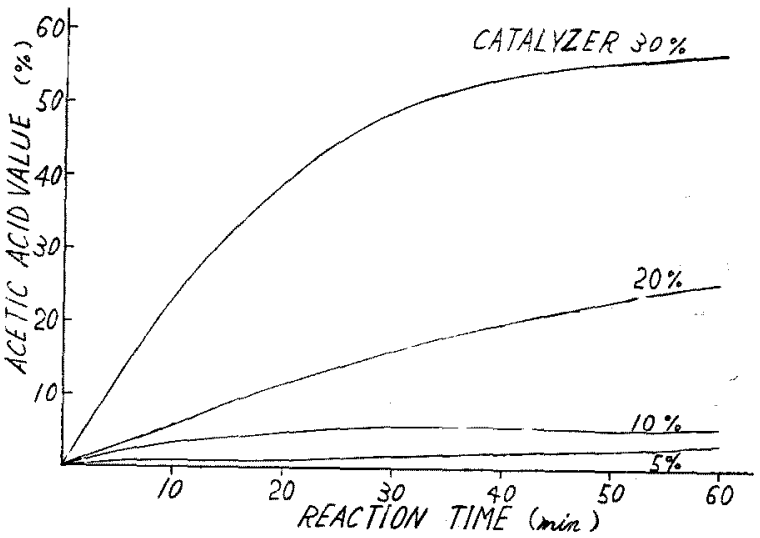

Fig 3. Combined acetic acid, in percent, of high tenacity rayon after acetylation reactions, at $120^{\circ} \mathrm{C}$, at various catalyzer concentrations. (weight ratio of acetic acid to cellulose, 1)

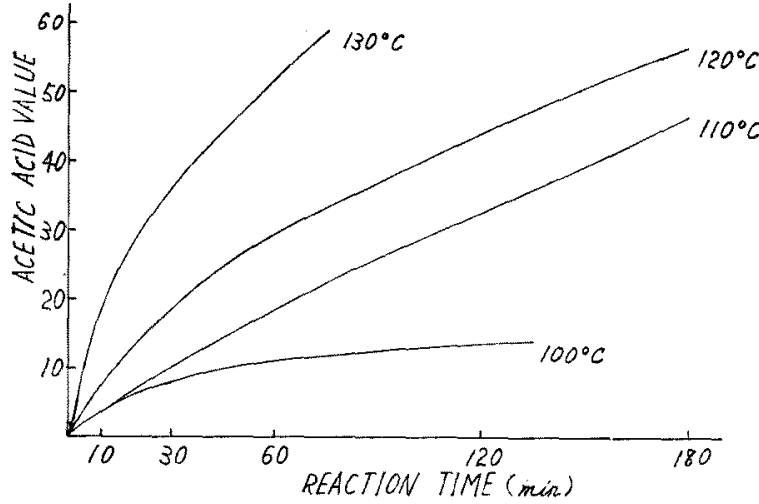

Fig 4. Combined acetic acid, in percent, of high tenacity rayon after acetylation reactions at various temperatures. (weight ratio of acetic acid to cellulose, 1)

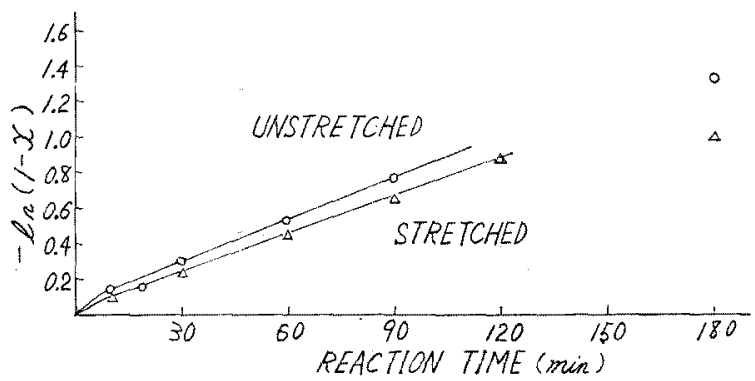

Fig 5. Comparison between acetylation reactions of high tenacity rayon under stretched and unstretched conditions.

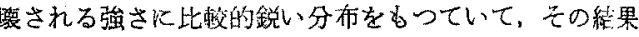
の一つの現われとして虺乾状熊です強力レーヨン住普通 レーョンに比較して，吕なり高い弾性的性質をるってい る。しか子普通レーヨンと強力レーヨンの 顕著な相遑仙ししるこの secondary network (無定形領域) の構造を完全に破壊す るような環境，具体的に梳相対湿度 $80 \%$ 以 上の湿潤状態に置いた場合に現われる。す な和ち普通レーヨンでは強力恃著しく低下 し, 弹性回復もきわめて悪くなるが, 強力 レーヨンではな掠大部分の強力を保持し， しかる弹性回復は乾燥状態上りるさらに良 好になることがかかる。この理由を考えて みると，要するに強力レーョン性普通レー ヨンK比較してより完全な primary network すなわら連続ミセル棈造ができてい ることによるるのであろう。具体的には network の結び目を形成している結晶領

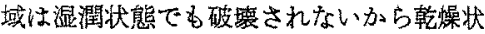
態とむまりちがわない強力をるち，この結 び目を連綕する無定形状熊の鎖状分子汇を のエントロピー弾性をより充分に発揮して 高い弹性回復を示すことができるが，一方 普通レーヨンではこの primary network が充分にはできていないなめ湿潤状態にし て secondary network を破聂するとこれ が同時に全体の組織を崩壊させ召結果とな り膨潤度る大きく強力。低下してしま5。 以上のよ5なことからより理想に近い primary network 構造をるつ強力レーヨンK 屯いて, 無定形領域の secondary network を構成している種々の結合なかんずくを の中心をなすとみられる水素結合の数，強 さなどを適度に調節することができれば機 诚的性質，特汇弹性的性質などを影著に改 善し得ることが期待される。この水菜結合 の強さ数などを調節する方法として物理 的, 物理化学的処理の性为種々 0 化学弅理

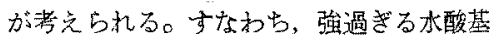
間の水翟結合を適度に弱めることができれ ば，それによつて前述のよ弓に無定形領域 のセルロース分子のェントマピー弹性はよ り充分に発揮できるようになるで方うう し，末だ多数の水素結合の代敞りに少数の 化学的架橋結合索入することができれば 適度な初期弾性率を保らながら高い弹性回 


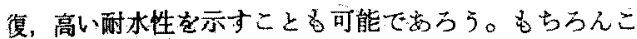
えらの化学的処理に上つて機械的性質が改善される一 面，吸湿性，吸水性，染色性など種々の变化をむたら すことは考虑されなければならない。以上の上うな観点 から手近に考充られる化学処理の一つにア七チル化があ る。セルロースあるいはレーヨンのアセチル化について

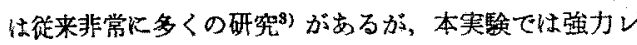
ーヨンの構造あるい性牲を種々㭲討する研究手段の一 ことしてこのアセチル化をとり上げ二，三実験した結果 灾報告する。

\section{2. 試料およひ実験}

原試料として注上に述べたよ5な連繶ミ七ル構造にな るべく近い構造をもつと思われるオールスキン型の強力 レーヨンを使用し，ア七チル化法としてはこれま上記 の镍点から primary network はなるへく变化させない いい換光れば secondary network の構成だけを変化さ せる意味から，当然ミセル不均一反纯機構をとると思わ れる械維状アセチル化が採用されな於ればならない。し

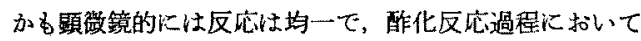
解重合の起こることの最も少いとみられる $\mathrm{CH}_{3} \mathrm{COONa}$ を触媒とする方法を用いた。すなおち前処理として所要 濃度の $\mathrm{CH}_{3} \mathrm{COONa}$ 水溶液に試料レーヨンを無緊張打上

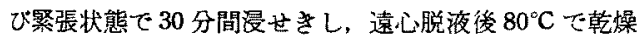
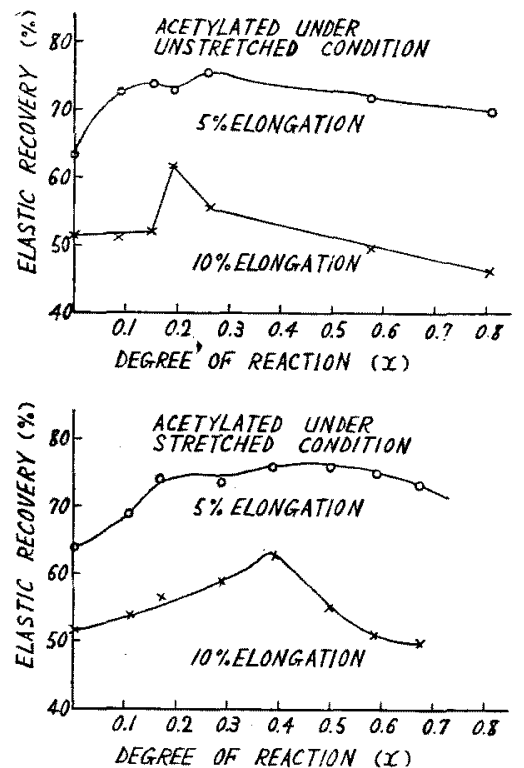

Fig 6. Relation between degree of reaction and elastic recovery.

乙無水酩酸 $120 \mathrm{cc}$, キシレン $20 \mathrm{cc}, \mathrm{CH}_{3} \mathrm{COONa} \cdot 3 \mathrm{H}_{2} \mathrm{O}$ $8 \mathrm{~g}$ の酷化浴中に漫せきし無緊張和よび熙張状態で所定

第 1 表無緊張酶化試料の强伸度

\begin{tabular}{|c|c|c|c|c|c|c|c|c|c|c|}
\hline \multicolumn{3}{|c|}{ 試 } & 料 & \multirow{2}{*}{$\begin{array}{r}\text { No. } 1 \\
0\end{array}$} & \multirow{2}{*}{$\begin{array}{l}\text { No. } 2 \\
9.24\end{array}$} & \multirow{2}{*}{$\frac{\text { No. } 3}{15.0}$} & \multirow{2}{*}{$\frac{\text { No. } 4}{18.5}$} & \multirow{2}{*}{$\frac{\text { No. } 5}{24.8}$} & \multirow{2}{*}{$\begin{array}{l}\text { No. } 6 \\
42.0\end{array}$} & \multirow{2}{*}{$\begin{array}{l}\text { No. } 7 \\
55.4\end{array}$} \\
\hline 酸 & ft & 度 & $(\%)$ & & & & & & & \\
\hline 緘 & & 度 & (d) & 2.37 & 2.74 & 2.81 & 2.83 & 3.24 & 3.56 & 3.91 \\
\hline 乾 & 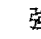 & 力 & (g) & 9.75 & 9.89 & 10.0 & 9.85 & 9.80 & 9.55 & 6.35 \\
\hline 乾 & 3 & 度 & $(g / d)$ & 4. 12 & 3.60 & 3.55 & 3.48 & 3.03 & 2.68 & 1.62 \\
\hline 湿 & 强 & 度 & $(\mathrm{g} / \mathrm{d})$ & 2.69 & 2.35 & 2.30 & 2.22 & 2.11 & 1.85 & 1.52 \\
\hline 伸 & & 度 & $(\%)$ & 13.9 & 19.4 & 21.3 & 20.2 & 21.2 & 24.5 & 28.9 \\
\hline 潨 & 轩 & 強 比 & $(\%)$ & 65.4 & 65.2 & 64.9 & 64.0 & 69.8 & 69.0 & 94 \\
\hline 反 & & 応 & 度 & 0 & 0.0925 & 0.155 & 0.195 & 0.268 & 0.570 & 0.815 \\
\hline
\end{tabular}

第 2 表緊張酢化試料の強伸度

\begin{tabular}{|c|c|c|c|c|c|c|c|c|c|c|}
\hline & 試 & 料 & No. 1 & No. 2 & No. 3 & No. 4 & No. 5 & No. 6 & No. 7 & No. 8 \\
\hline 䣷 & 化 & 度 $(\%)$ & 0 & 11.55 & 15.7 & 25.4 & 32.5 & 39.5 & 44.3 & 48.7 \\
\hline 膟 & & 度（d) & 2.37 & 2. 65 & 2.67 & 2.86 & 3.15 & 3.33 & 3.35 & 3.47 \\
\hline 颠 & “強 & 力 $(g)$ & 9. 75 & 9.34 & 9.25 & 10.1 & 9.35 & 9.99 & 10.08 & 10.25 \\
\hline 黄 & 強 & 度 $(\mathrm{g} / \mathrm{d})$ & 4. 16 & 3.52 & 3.44 & 3.52 & 3.06 & 3.00 & 3.01 & 2.96 \\
\hline 湿 & 岾 & 度 $(\mathrm{g} / \mathrm{d})$ & 2.68 & 2.19 & 2. 21 & 2.10 & 2.09 & 2.32 & 2.07 & 2.00 \\
\hline 伸 & & 度 $(\%)$ & 13.5 & 14.75 & 16.8 & 16.0 & 16.8 & 15.5 & 15.1 & 16.1 \\
\hline 混 & 暲 強 & 比 $(\%)$ & 64.5 & 63.0 & 64.2 & 60.0 & 62.0 & 67.3 & 65.5 & 67.5 \\
\hline 反 & 応 & 度 & 0 & 0.107 & 0.162 & 0.280 & 0.380 & 0.490 & 0.575 & 0.660 \\
\hline
\end{tabular}


の温度で酢化を進めた。無緊張および祭張酢化 試料の $5 \%$ 洛よぴ 10\%伸長上りの弾性回復率 は $5 \%$ 牤よび 10\% までの伸長所要時間をそれ 艺れ $30 \mathrm{sec}, 1 \mathrm{~min}$ とし. 除重後 $1 \mathrm{~min}$ の回復率 を測定した。酷化試料のX線解析注理学電機 社製 Geiger Flex 使用し赤道力向の干涉強度 曲線を測定した。

\section{3. 実験結果および考察}

触媒濃度之酢化反応経過の関倸の一例劣第 3

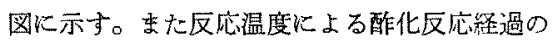
相違を第 4 図に示す, さらに原試料の乾燥状態 の長さに緊張固定して前処理就よび酢化を行な つた場合を無緊張でこれを行なつた照合を比較 した(第 5 図)。反応のごく初期と比較的末期を 除けばいずれも見掛け上一分子反応式に適合す るから, 反応度 0.5 以下のこの範围では試薬の 渗透拆散が律速段階ではなく, 無定形領域に反 応はかなり均一飞近く進むことが推定される。 緊張した場合と無緊張の場合とで反応速度には 大きな相違がみられない。紫張した場合の方が や必低い反応度から一次反応経過より偏いする 傾向がみられる。次にこのよ5にして製造した 無緊張括よび緊張酷化試料の機械的性質を測定 した結果を第 1〜2 表に示す。強力は無緊張の 場合ある酢化度で最高を示し，去れ以上酢化 度が昇ると低下するが，緊張酸化の場合心か极

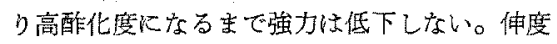
は無婜張酢化では大きな值を示し, 強力の低下

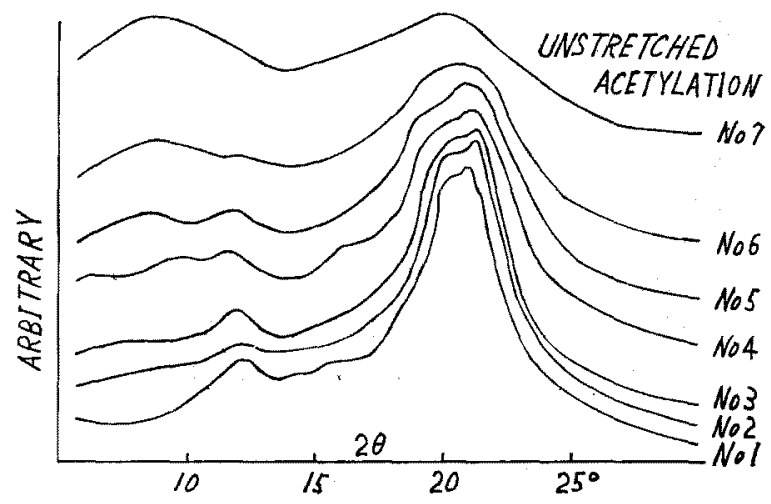

Fig 7. X-ray diffraction patterns along the equator of the samples acetylated under unstretched condition.

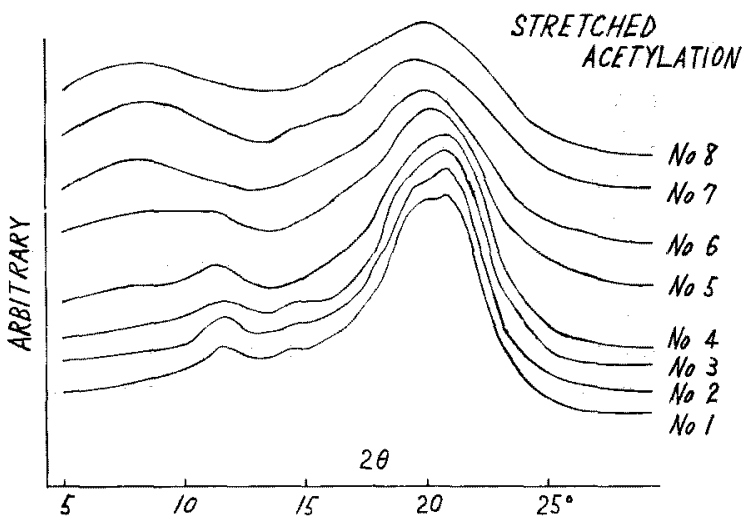

Fig 8. X-ray diffraction patterns along the equator of the samples acetylated under stretched condition.

を示す段階からさらに增大するが，これは反応経過に起 こる収穛に対応している。祭張䤏化試料では当然ながら

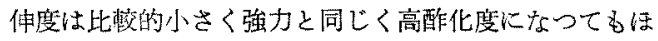
とんど変和らない。 $5 \%$ 扣よび $10 \%$ 伸長上りの弾性回 復签忛 6 図に示した。

この図からわかるよ5にいずれも醀化反応の初期，比 較的酰化度の低い段階で弾性回復率任向上し，以後むる

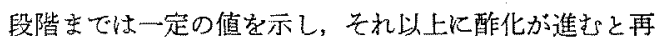
び弹性回復举動は墨化する。すなるら酢化反応忙すず㯪

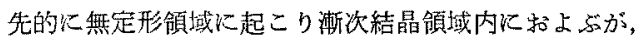

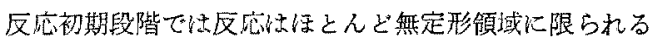
ために結晶領域を結び目とする primary networkは茟 全に保持されたをを secondary network を構成する水 酸基間の強い水素結合が次第にアセチル基間の比較的弱 い結合に置き撸えられていくため，前述の理由によって 弾性的な性質は向上する。しかるにさらに酢化が進んで 結晶領域に扣よんでくるにつれて primary network の

結び目は崩罱ないしは弱化するから弹性回復举動はまた 次第纪低下する。伸長率 $5 \%$ ，10\% の而者を比較する そ, $10 \%$ 万が弹性回復挙動が向上する点が高酢化度側 にずれている。これはいらまでるな $10 \%$ 伸最の場合 は $5 \%$ 伸長に比較して変形はラテラルオーダーのより高 い領域にまで拉よら゙から，眽化がその領域にまで進み， したがつて全体の酢化度るより高くならないと弾性回復 挙動は向上してこない。しかしてその段階では結晶領城 もすでに相当酢化され primary network の結び目もむ る程度崩擐する加ら，弾性回復率も充分高くならず，它

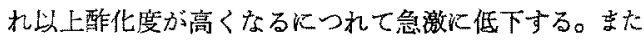
無緊張醈化のものと緊張酢化のるのとを比較すると，前 者の方が低醀化度ですで弾性回復挙動が向上する。こ の理由は確赛てはないが両者の酢化反応の均一，不均一 性の多少の差異によるるのではないかと考えられる。最 後に酢化反応がすでに还べたような目的に適合するよう な様式で起こつているか否かる゙検討するために，各試料 
のX線干涉它測定した。結果は第7,8図に示すようで無

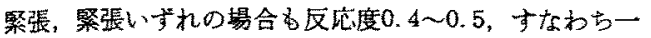

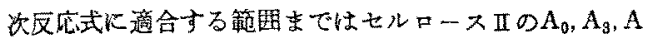
4の干涉点はほとんど䕱著な变化を示さず，反応はもつ ばら無定形領域怙よび結晶領域の表面に起こり，結晶領 域内部变化しないことがわかる。しかしてこの段階で

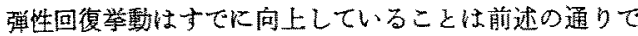
ある。反度度がさらに進めばようやくセルロースエの干 涉点は不明暸になり反応が結晶領域内部に進行したこと

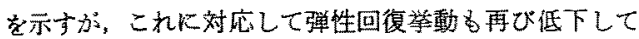
きて，ほぼ期待される反応機構を裏畫きしているよ5に 思方える。

以上の実験結果から強力レーシンの微細榡造，それの

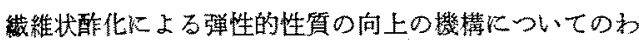
れかれの若え方が大体莫当であることはわからたがなお 弹性回复举動，耐水性などの点で満足できない点も多い。 この原因体るるんいるいるあるが最も㮛本的には原料 の強力レーヨンが必ずしも理想的な primary network 構造を具備していないことと、ここに採用したような酢

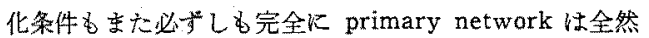
変化せず，無定形領域だけを酢化しているるのでるない ことである。従つてこれからのこの方面のレーミンの発 展にとつて重要なことはまず理想的な primary network を有する原料レーヨンを製造することである。しかる後 不均一䣷化，㐫るいは種々の化学的架橋化処理により無 定形領域を調整することによつて，レーヨンの性質はな

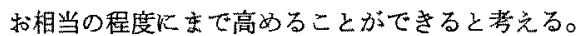

\section{4. 絰括}

オールスキン型強力レーヨンはかなり double network
に近い微細棈造をもつているものと考克られる。従つて primary network (無定形領域) の結び目を構成する水素結合を適当に二 ントロールすることがでされば，強度，耐水性，弹性な どのすくれれた織維を得ることができると考えられる。こ

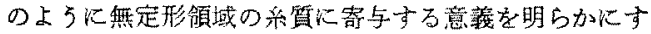

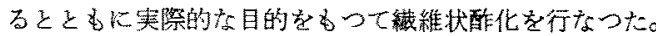

酷化処理の触媒としては $\mathrm{CH}_{3} \mathrm{COONa}$ 用い，無酢一 キシレンー $\mathrm{CH}_{3} \mathrm{COONa}$ 系で試数を無䁷張就よび緊張状熊 厄及度行教つた。

1. 滴当な条件下においてはする範用内で酢化は1次 反応様式他徒5。

2. レーヨンの無定形領域が眽化されたと考充られる

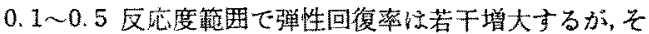

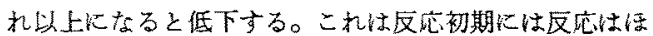
とんど無定形領域に限られるため，結晶領域を結び目と する primary network は经全に保持されたま secondary network を構成する水酸基間の強い水素結台がフ セチル基の弱い結合に置換されるために弹性的性質は向 上する。

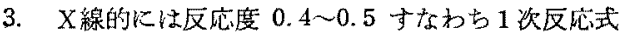

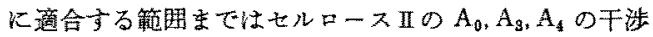
点は㩆著な变化を示さない。反応がさらに進むとせルロ ースIIの干涉点は不明瞭となる。

文 献

1) P. Herrent, A. Lude ; Text. Res.J., 21, 137 (1951)

2) 前田; 第 4 回東京化緎研究会講演集，p. 1 (1958) 前田；高分子， 10, 509 (1961)

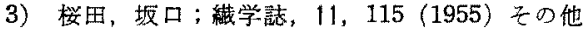
永井，木谷; 東邦レ報告，4，15(1957) など

(的和 36 年 9 月 14 日 受理)

強力レーヨンの微細構造と疲労性との関係について

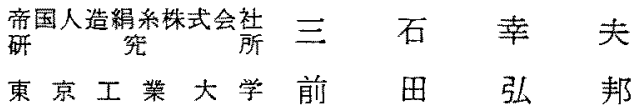

\section{THE RELATIONSHIP BETWEEN FINE STRUCTURE OF HIGH TENACITY RAYONS AND THEIR FATIGUE PROPERTIES}

By Yukio Mitsuishi

(Research Laboratory, Teikoku Rayon Co., Ltd., Iwakuni City, Yamaguchi Prefecture, Japan)

By Hirokuni Maeda

(Laboratory of Textile Chemistry, Tokyo Institute of Technology, Meguro-ku, Tokyo, Japan) 